\title{
Article
}

\section{Outstanding Primary Leadership in Times of Turbulence}

\author{
Colin Howard *(i) and Jaswinder K. Dhillon (1) \\ School of Education, University of Worcester, Worcester WR2 6AJ, UK; j.dhillon@worc.ac.uk \\ * Correspondence: c.howard@worc.ac.uk
}

Citation: Howard, C.; Dhillon, J.K. Outstanding Primary Leadership in Times of Turbulence. Educ. Sci. 2021, 11, 714. https://doi.org/10.3390/ educsci11110714

Academic Editor: Krishan Kumar Sood

Received: 17 September 2021

Accepted: 22 October 2021

Published: 6 November 2021

Publisher's Note: MDPI stays neutral with regard to jurisdictional claims in published maps and institutional affiliations.

Copyright: (C) 2021 by the authors. Licensee MDPI, Basel, Switzerland. This article is an open access article distributed under the terms and conditions of the Creative Commons Attribution (CC BY) license (https:// creativecommons.org/licenses/by/ $4.0 /)$.

\begin{abstract}
Leadership and management in schools have sought to produce high quality education for all pupils. To inform and support school leaders' educationalists have developed theories and undertaken research studies identifying the relationships, contexts and characteristics that enable effective leadership. However, recent times of turbulence in primary schools have had an inevitable impact upon the key drivers for successful leadership and management. This study builds upon our previous research into outstanding leadership in primary education to examine the impact that such change has had upon the leadership of serving head teachers. It utilises an adapted Q-sort methodology to identify the views of serving head teachers to gain insights into the impact that such change has had upon their leadership. Overall, the analysis identified a need for aspirational characteristics of leadership, underpinned by personal values to guide schools in such times, as they strive to produce high quality education.
\end{abstract}

Keywords: leadership; primary education; Q-methodology; turbulent times; COVID-19; leadership and management

\section{Introduction}

No one could have anticipated the scale of crisis for schools as a result of the large-scale impact of COVID-19 on the daily (operational) and strategic lives of school leaders and their leadership teams. Even in 'normal times' authors [1], have suggested that effective and strong leadership are important in driving forward strategic change and innovation in schools. However, given the turbulence driven by the pandemic the need for outstanding leadership to ensure that the quality of education can survive and flourish is more vital than ever. Though the conception of leadership and leadership practices have changed dramatically $[2,3]$. Leadership has needed to be flexible and reactive to such times of crisis so that they may continue to secure the highest quality of education for the pupils in their care. During this crisis much focus has been on schools being able to deal with swift and sudden change in a timely manner. Such responses however must not be seen in isolation as they have been forged in a context of national guidance, advice and statutory change. One thing that has been demonstrated is that where change and uncertainty are common outstanding leadership is needed more than ever. We propose that outstanding leadership involves individuals who are adaptive and driven by the pursuit of excellence, whatever the context in which they provide leadership. This includes times of turbulence and crisis, such as a pandemic where they have to respond quickly to rapidly changing circumstances. In the following sub-section, we review research literature on leadership that is relevant to this study.

\section{The Context for Leadership}

Recent research and articles on school leadership during the COVID-19 pandemic have referred to leadership as being in 'crisis' [2-4]. Some of this published research draws on the literature on crisis leadership $[4,5]$ to understand the challenges faced by schools and the impact of the global crisis on school leadership [5]. The scale and scope of the challenges brought about by COVID-19 are unprecedented. For many school leaders and 
managers dealing with the pandemic has presented a once in a lifetime challenge for their leadership, so it could be seen as a crisis. However, we prefer leadership to be considered as being in a state of turbulence rather than in crisis. Such a nuanced difference is the result of ongoing instability in education due to the pandemic. For many school leaders their daily leadership roles have changed dramatically. For example, in England, leaders' roles now include implementing daily safety procedures as specified by government agencies [6]. They are having to respond to a backdrop of constantly changing government guidance and organizational demands as a result of the pandemic ebbing and flowing. Hence our preference for the use of the term turbulence rather than crisis.

Prior to this pandemic, aspects of innovation and change in education may be linked to political expedience [7]. In the English education system change has been allied to government policy to drive up standards in an environment of increased accountability. Such strong accountability has been overseen and made public by quality assurance organisations such as the Office for Standards in Education (Ofsted), as noted by [8]. Even before the pandemic headteachers were dealing with underlying worrying concerns, including teacher recruitment and retention, mental health and wellbeing and supporting disadvantaged pupils against a backdrop of limited finances. The pandemic brought a shift in priorities for day-to-day decision making, some of which have been documented in research studies [5,9] that show the resilience and re-negotiation of leadership qualities and characteristics. They include the importance of trust [10] and the development of care [9] alongside the commitment to values and vision which are also prominent characteristics identified by earlier research into successful school leadership.

Empirical studies [11,12], have sought to understand characteristics of successful, effective and outstanding leadership in schools but as yet little work has been undertaken to examine the impact of times of crisis or turbulence on these characteristics. Research into how school leaders are responding to this pandemic is however evolving $[3,5,9,13]$, as educational researchers seek to investigate the impact of a period of crisis on schools and school leadership. This article builds on our previous study of characteristics of outstanding leadership in primary education [12] to investigate how primary school leaders now perceive and identify with such characteristics in the light of this ongoing turbulence.

\section{Methodology and Methods}

\subsection{Context of the Study}

The research reported here draws on a wider study [12], in which we used Qmethodology to develop and validate a set of characteristics of outstanding leadership. Q-methodology has not been widely applied to the study of educational leadership and like other methods of research has its critics and proponents [14]. Our choice was influenced by its novelty and versatility and we outline below the methodology used to develop the statements and how they were used in the research reported here. Ethical approval was obtained from the University of Worcester ethics committee and both university and professional association guidelines for ethical research followed through all stages of the research process [15].

Q-methodology was originally developed by psychologist William Stephenson to provide a systematic study of subjectivity within qualitative aspects of human behaviour [16]. Fundamental to the methodology is the concept of operant subjectivity. Subjectivity is understood as the activity relative to the immediate environment, that constitutes a person's current viewpoint. Conducted through the lens of operant subjectivity Q-methodology offers an interactive, dynamic and operant means of engaging respondents in their selfreference subjectivity from which viewpoints, perceptions and attitudes are discovered.

In our wider original study, this was stakeholders' perceptions of outstanding leadership in different educational contexts. The contexts encompassed different age phases: primary, secondary and post-compulsory education in urban and rural settings and involved collaboration between those working in professional practice settings (e.g., schools) and those in academic institutions (e.g., universities). For the purposes of this article, we 
draw on the results from the original study for the primary age phase of education in England. We outline below the research process used to develop statements of outstanding leadership using Q-methodology and then discuss the design of the follow-up work that generated the results presented in Section 3 of this article.

\subsection{Methods and Analysis}

Q-methodology is a structured process with an order of interdependent stages. We followed the approach [17], which is represented in a simplified form in Figure 1:

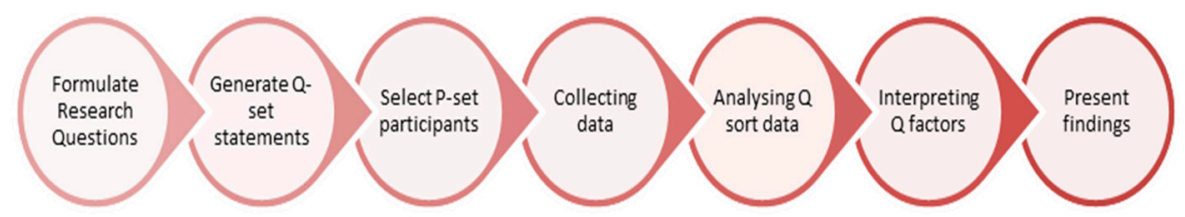

Figure 1. Stages in Q-methodology.

The stages in the process shown in Figure 1 were followed to generate and validate statements representing the viewpoints of a range of stakeholders on characteristics of outstanding leadership. The stakeholders included school and college leaders and managers, members of school and college governing bodies, researchers and academics in the field of educational leadership and management and education professionals studying on leadership development programmes.

The development and refinement of the statements was a collaborative, reflective and iterative process in which we sought to achieve a synthesis of viewpoints from theory and current professional practice in the field of leadership and management. Our own past and current professional experience, as leaders, managers and governors in different age phases of education also informed our research approach. The first stage of this process was a literature review of theory, policy and empirical research on successful and effective leadership $[11,18,19]$ to draft statements which were piloted in workshops with education professionals. Respondents in the pilots were invited to consider the draft statements, reflect on the notion of outstanding leadership and amend and add to the bank of statements to reflect their viewpoints. Our aim was to generate a set of Q-set statements which reflected current views of outstanding leadership practice. The outcome was the 23 statements shown in Table 1.

Table 1. Q-set statements: 23 characteristics of outstanding leadership.

\begin{tabular}{ccc}
\hline $\begin{array}{c}\text { Clear strategic vision and } \\
\text { communicated effectively to } \\
\text { others (1) }\end{array}$ & $\begin{array}{c}\text { Passion for providing world } \\
\text { class education (2) }\end{array}$ & $\begin{array}{c}\text { Strategic vision based on } \\
\text { shared values (4) }\end{array}$ \\
\hline $\begin{array}{c}\text { Inspirational leader who leads } \\
\text { by example (5) }\end{array}$ & $\begin{array}{c}\text { High levels of trust between } \\
\text { leaders and their stakeholders } \\
(7)\end{array}$ & $\begin{array}{c}\text { Ability to bring out the best in } \\
\text { people and inspire others (8) }\end{array}$ \\
\hline $\begin{array}{c}\text { Power and accountability } \\
\text { shared and distributed } \\
\text { amongst members of } \\
\text { leadership team (10) }\end{array}$ & $\begin{array}{c}\text { Ability to foster discussion } \\
\text { and debate (11) }\end{array}$ & $\begin{array}{c}\text { High expectations of all } \\
\text { members of staff and } \\
\text { pupils /learners (13) }\end{array}$ \\
\hline $\begin{array}{c}\text { An open culture of learning } \\
\text { where excellence in all aspects } \\
\text { of achievement are celebrated } \\
(14)\end{array}$ & $\begin{array}{c}\text { Foster collaboration, } \\
\text { partnerships and shared } \\
\text { decision-making (16) }\end{array}$ & $\begin{array}{c}\text { Values and vision developed } \\
\text { and owned by all members of } \\
\text { staff and governors (17) }\end{array}$ \\
\hline
\end{tabular}


Table 1. Cont.

\begin{tabular}{ccc}
\hline $\begin{array}{c}\text { Setting ambitious targets and } \\
\text { maintaining clear focus on } \\
\text { achieving financial as well as } \\
\text { educational/academic goals } \\
\text { (18) }\end{array}$ & $\begin{array}{c}\text { Empowering others to achieve } \\
\text { ambitious targets (19) }\end{array}$ & $\begin{array}{c}\text { Meticulous monitoring of } \\
\text { outcomes for pupils/learners } \\
\text { (20) }\end{array}$ \\
\hline $\begin{array}{c}\text { Reconciling opposing points } \\
\text { of view and summarising } \\
\text { agreed points to leadership } \\
\text { teams (21) }\end{array}$ & $\begin{array}{c}\text { Taking decisive action to } \\
\text { address poor performance of } \\
\text { staff teams e.g., senior, middle } \\
\text { leaders, curriculum teams, } \\
\text { pastoral support (22) }\end{array}$ & $\begin{array}{c}\text { Taking difficult decisions and } \\
\text { communicating them honestly } \\
\text { to those affected (23) }\end{array}$ \\
\hline $\begin{array}{c}\text { Balancing financial constraints } \\
\text { with aspirational educational } \\
\text { ambitions (3) }\end{array}$ & $\begin{array}{c}\text { Maximising talent in the team } \\
\text { and deploying talent } \\
\text { effectively in the organisation } \\
\text { (9) }\end{array}$ & $\begin{array}{c}\text { Engaging the local community } \\
\text { in developing a shared vision } \\
\text { for educational provision in } \\
\text { the area (6) }\end{array}$ \\
\hline $\begin{array}{c}\text { Develop entrepreneurial and } \\
\text { innovative approaches to } \\
\text { improve education (12) }\end{array}$ & $\begin{array}{c}\text { Developing an aspirational } \\
\text { culture in the school/college } \\
\text { and local community (15) }\end{array}$ & \\
\hline
\end{tabular}

It is important to note that no ranking of the statements was involved at this stage. The numbers at the end of each statement shown in Table 1 were randomly allocated. This was merely a shorthand way of referring to each statement for collecting data using a Q-sort grid (tool for data collection) and for processing and analysing the derived data using Q-method software.

The ranking of the statements came during the subsequent stages of the Q-methodology process. For data collection a Q-sort grid or concourse with a seven point range from -3 to 3 including 0 (zero) was produced. The distribution grid had 23 places for placing the 23 statements of outstanding leadership. Thus, in completing the Q-sort grid respondents were making relative choices between those they thought most significant characteristics of outstanding leadership (most agreed) and those they thought less significant (least agreed). In recording their choices respondents wrote the numbers at the end of the statement on the recoding sheet rather than writing out the full text of each statement. The data from the recording sheets was processed by Q-method software to produce rankings of the statements for all respondents $(n=68)$ and by age phase and stakeholder type.

For the purposes of this article, we use some of the results of the analysis for primary education settings $(n=14)$. They reflect the viewpoints of respondents before the COVID-19 pandemic, thus before a time of crisis and turbulence. We used the 5 most agreed and the 5 least agreed statements for primary education from our original study as a stimulus for online interviews with serving primary school headteachers in England.

\subsection{Participants}

Semi-structured online interviews were carried out after the second wave of COVID19 lockdown in England (between spring and early summer 2021) after headteachers had steered their schools through a year of exceptional turbulence. A purposive sample of primary school headteachers were invited to participate in the study. Nine leaders were approached and sent an invitation letter, a participant information sheet and a consent form. Due to pressure on those originally approached, as a result of the pandemic, only four respondents agreed to take part in the study. These respondents were asked to rank the Q-sort statements giving their 5 most agreed and the 5 least agreed statements with regards to securing outstanding leadership during the pandemic. After completing the ranking of the Q-sort statements, three out of the four leaders agreed to be interviewed on-line to discuss the reasoning and thinking behind how they had ranked each item.

The respondents in the study represent a range of school size (from 100-600 pupils on roll). Leader 1 is an established long standing headteacher with over 20 years of headship 
experience both nationally and internationally. He is currently leading a large urban primary school in inner London with over 600 pupils. Leaders 2, 3 and 4 are located in the West Midlands. Leader 2 has over 15 years of headship experience and she is head of a semi-rural school with 100 pupils on roll. Leader 3 has over 25 years of headship experience and runs a school with 200 pupils on roll set in a semi-rural setting. Leader 4 has been a headteacher for over 10 years and she runs a small rural primary school. Each on-line interview was recorded with the consent of the respondent and transcribed verbatim for analysis and interpretation. It is the results from these Q-sorts and interviews that are presented in the following section.

\section{Findings}

\subsection{Most Agreed Characteristics of Outstanding Leadership}

Table 2 shows the result of the Q-sorts respondents most agreed when reflecting on characteristics of outstanding leadership in primary education. The original study results are highlighted in grey.

Table 2. Most overall agreed characteristics by ranking.

\begin{tabular}{|c|c|c|c|c|c|}
\hline & \multicolumn{5}{|c|}{ Most Agree and by Rank Order } \\
\hline & 1 & 2 & 3 & 4 & 5 \\
\hline Original Study & $\begin{array}{c}\text { High } \\
\text { expectations of } \\
\text { all members of } \\
\text { staff and } \\
\text { pupils (13) }\end{array}$ & $\begin{array}{l}\text { Maximising } \\
\text { talent and } \\
\text { deploying it } \\
\text { effectively in } \\
\text { the } \\
\text { organisation } \\
\text { (9) }\end{array}$ & $\begin{array}{l}\text { Taking decisive } \\
\text { action to } \\
\text { address poor } \\
\text { performance of } \\
\text { staff (22) }\end{array}$ & $\begin{array}{l}\text { Inspirational } \\
\text { leader who } \\
\text { leads by } \\
\text { example (5) }\end{array}$ & $\begin{array}{l}\text { Ability to bring } \\
\text { out the best in } \\
\text { people and } \\
\text { inspire others } \\
\text { (8) }\end{array}$ \\
\hline Leader 1 & $\begin{array}{l}\text { Clear strategic } \\
\text { vision and } \\
\text { communicated } \\
\text { effectively to } \\
\text { others (1) }\end{array}$ & $\begin{array}{c}\text { An open } \\
\text { culture of } \\
\text { learning where } \\
\text { excellence in } \\
\text { all aspects of } \\
\text { achievement } \\
\text { are celebrated } \\
(14)\end{array}$ & $\begin{array}{l}\text { Taking difficult } \\
\text { decisions and } \\
\text { communicat- } \\
\text { ing them } \\
\text { honestly to } \\
\text { those affected } \\
\text { (23) }\end{array}$ & $\begin{array}{c}\text { Foster } \\
\text { collaboration, } \\
\text { partnerships } \\
\text { and shared } \\
\text { decision- } \\
\text { making } \\
(16)\end{array}$ & $\begin{array}{c}\text { Values and } \\
\text { vision } \\
\text { developed and } \\
\text { owned by all } \\
\text { members of } \\
\text { staff and } \\
\text { governors (17) }\end{array}$ \\
\hline Leader 2 & $\begin{array}{l}\text { Values and } \\
\text { vision } \\
\text { developed and } \\
\text { owned by all } \\
\text { members of } \\
\text { staff and } \\
\text { governors (17) }\end{array}$ & $\begin{array}{l}\text { High levels of } \\
\text { trust between } \\
\text { leaders and } \\
\text { their } \\
\text { stakeholders } \\
\text { (7) }\end{array}$ & $\begin{array}{c}\text { An open } \\
\text { culture of } \\
\text { learning where } \\
\text { excellence in } \\
\text { all aspects of } \\
\text { achievement } \\
\text { are celebrated } \\
(14)\end{array}$ & $\begin{array}{l}\text { Developing an } \\
\text { aspirational } \\
\text { culture in the } \\
\text { school/college } \\
\text { and local } \\
\text { community } \\
\text { (15) }\end{array}$ & $\begin{array}{l}\text { Reconciling } \\
\text { opposing } \\
\text { points of view } \\
\text { and } \\
\text { summarising } \\
\text { agreed points } \\
\text { to leadership } \\
\text { teams (21) }\end{array}$ \\
\hline Leader 3 & $\begin{array}{l}\text { Clear strategic } \\
\text { vision and } \\
\text { communicated } \\
\text { effectively to } \\
\text { others (1) }\end{array}$ & $\begin{array}{l}\text { High levels of } \\
\text { trust between } \\
\text { leaders and } \\
\text { their } \\
\text { stakeholders } \\
\text { (7) }\end{array}$ & $\begin{array}{l}\text { Taking difficult } \\
\text { decisions and } \\
\text { communicat- } \\
\text { ing them } \\
\text { honestly to } \\
\text { those affected } \\
\text { (23) }\end{array}$ & $\begin{array}{c}\text { Foster } \\
\text { collaboration, } \\
\text { partnerships } \\
\text { and shared } \\
\text { decision- } \\
\text { making } \\
(16)\end{array}$ & $\begin{array}{c}\text { Engaging the } \\
\text { localcommu- } \\
\text { nity in } \\
\text { developing a } \\
\text { shared vision } \\
\text { for educational } \\
\text { provision in } \\
\text { the area (6) }\end{array}$ \\
\hline Leader 4 & $\begin{array}{l}\text { Clear strategic } \\
\text { vision and } \\
\text { communicated } \\
\text { effectively to } \\
\text { others (1) }\end{array}$ & $\begin{array}{l}\text { Taking difficult } \\
\text { decisions and } \\
\text { communicat- } \\
\text { ing them } \\
\text { honestly to } \\
\text { those affected } \\
\text { (23) }\end{array}$ & $\begin{array}{l}\text { High levels of } \\
\text { trust between } \\
\text { leaders and } \\
\text { their } \\
\text { stakeholders } \\
\text { (7) }\end{array}$ & $\begin{array}{l}\text { Inspirational } \\
\text { leader who } \\
\text { leads by } \\
\text { example (5) }\end{array}$ & $\begin{array}{l}\text { Reconciling } \\
\text { opposing } \\
\text { points of view } \\
\text { and } \\
\text { summarising } \\
\text { agreed points } \\
\text { to leadership } \\
\text { teams (21) }\end{array}$ \\
\hline
\end{tabular}

There are strong agreements overall as well as nuanced differences in views amongst the fourteen leaders in the original study (highlighted in grey in Table 2) and those in 
the follow-up research. In the original study the six most agreed statements reflected positive aspirational and inspirational characteristics of leadership. These included, high expectations, maximising talent and deploying it effectively, inspirational leader who leads by example, bringing out the best in people, inspiring others, developing an aspirational culture but also include 'taking decisive action to address poor performance of staff'.

However, in the data gathered during a time of turbulence, (COVID-19 pandemic), aspirational and inspirational characteristics are superseded by other characteristics, which are discussed below. It also is important to note as Leader 1 suggested:

Every school is different and so how one school does it might be different to another school because of the context of the school, the site, staff makeup, (staff cannot come in COVID whilst due to size of schools others can open).

The most dominant ranked characteristic during a time of turbulence, (see Table 2) involved having a clear strategic vision communicated effectively to others (1). Second most highly ranked involved celebrating an open culture (14), with trust (7) being allied to taking difficult decisions and communicating them effectively (23). Lower rankings were given to statements such as fostering collaborative partnerships, inspirational leader who leads by example (5) and shared decision making (16), alongside reconciling opposing points of view (17).

Vision and values clearly seemed important for leaders and leadership teams in a time of turbulence. One leader noted "at times of stress and challenge we rely on relationships, it's the principles that drive us more than ever before" (Leader 2). Another commented "even more important with Covid, again it is just making sure that people are buying into what we are saying whether this is a managerial situation" (Leader 1). In such times, clear strategic vision would seem to be very important for school leaders. For such leaders it is about being really clear in one own's head about what is required and how you are going to get to it in practice. As Leader 3 suggested:

The staff and the community as a whole had confidence that someone there was making the decisions and driving the thing. It was most important that we all had that sense of we know where we are going and why.

Leaders interviewed suggested that in times of turbulence you need to be very clear about the direction the school must go in and that they were clearly driving things forward with clarity and conviction. That other stakeholders have confidence in the decisions their leadership were making and that the right decisions were being taken for the good of all.

Trust was also a common characteristic that needed to be displayed by leadership. It was noted that at times of turbulence leaders rely heavily on their staff to be independent and able to get on with their own roles and that trust is fundamental to this. For Leader 1, all prior interpersonal work with staff as a leader in ordinary times acted as a reservoir of goodness that could be drawn on at times of turbulence. Such previously valued acts from leaders to their staff meant that other individuals in their team could now be trusted and relied upon to do their best given their previous actions. As he noted, "we draw most heavily on people's goodwill, their trust, it's like we banked those values and virtues and we draw on them". Similarly, it was also suggested that trust was needed by all school stakeholders in their leaders during such difficult times:

We needed to bring the school community along with us ...... that we were acting with integrity with the best interests of everyone at heart really. We have a really good sense of school community here and that level of trust we already had, was built on, that it was essential it was there (Leader 4).

For Leader 2 trust was linked to the need to have an open culture where all stakeholders are in it together in terms of encouragement, taking initiatives and are individuals all on a learning journey together. Leader 2 noted:

It is so important that we develop a culture across the school not just the children but for adults as well where we see ourselves as learners and we encourage initiatives, that we encourage people to develop themselves. 
Obviously key decisions needed to be made around issues regarding COVID and Leader 2 suggested, "that is about making difficult decision, against mitigating risk and still making sure we have a broad, balanced and ambitious curriculum".

In times of turbulence, it is important for leaders to take difficult decisions and as identified in the Q-sort data to be able to reconcile opposing points of view (statement 17). Relationships were seen as being key to open and honest conversations given the circumstances leaders were facing. As Leader 1 suggested it included:

Their emotions, their fears, their backgrounds, lots and lots of people carry background stuff at the moment, to do with family, bereavement and concerns and it all comes in a big melting pot.

This meant difficult conversations where "every second of every interaction is about filling up that hole again, and keeping those relationships alive" (Leader 1).

Leaders could not act alone to secure the capacity needed to make their way successfully through the turbulence as noted by two of the leaders interviewed:

Working at teams enables that to happen. Being in it together gives people ownership rather than being directed from the top. With staff working remotely you are really relying on teams to work effectively and to collaborate with one another (Leader 2).

You may not think and feel the same as the person next to you but we have to take care of everyone... We have got to bring everyone along and even though you may not be anxious we are implementing this because $A, B, C$ are anxious so we have to do it for their sake. It is important that we didn't leave anyone behind (Leader 4).

Leaders did not want to make a bad situation worse. Also given the background of ongoing issues in 'ordinary times' in relation to secure staffing levels and to retain staff leaders were mindful of the long-term effects any conversations may have in the future. The wellbeing and mental health of individuals in schools were already paramount in leaders' minds prior to the pandemic. The additional pressures of working in the pandemic meant that these issues became even more important. Leaders need to support individuals not only to survive but thrive, not only now but in future. Leader 1 felt it would be counterproductive to be anything other than someone staff could turn to for support and advice. He pondered whether "we now shifting quite consciously to compassionate leadership in what we do? Because a didactic, autocratic style is not just appropriate for the context and situation we are in" (Leader 1).

However, Leader 4, from the smallest school in our sample, felt that at times of turbulence it was important to be an inspirational leader that led by example (5). Leader 4 suggested they needed to lead from the front:

Being there in the thick of it, alongside everyone, doing the same things as everyone else really. I think it much easier in a small school community to be one of the communities doing the same as everyone else.

Leader 4 however noted that for leaders of bigger schools such a role was possibly less relevant given the size and enormity of their role. They suggested a need to distribute leadership in order to make this task more manageable.

\subsection{Most Disagreed Characteristics of Outstanding Leadership}

Table 3 shows the result of the Q-sorts respondents most disagreed when reflecting on characteristics of outstanding leadership in primary education. The original study results are highlighted in grey. 
Table 3. Most overall disagreed characteristics by ranking.

\begin{tabular}{|c|c|c|c|c|c|}
\hline \multicolumn{6}{|c|}{ Most Disagree and by Rank Order } \\
\hline & 1 & 2 & 3 & 4 & 5 \\
\hline $\begin{array}{c}\text { Original } \\
\text { Study }\end{array}$ & $\begin{array}{l}\text { Passion for } \\
\text { providing } \\
\text { world class } \\
\text { education (2) }\end{array}$ & $\begin{array}{l}\text { Ability to } \\
\text { foster } \\
\text { discussion } \\
\text { and debate } \\
\text { (11) }\end{array}$ & $\begin{array}{l}\text { Develop en- } \\
\text { trepreneurial } \\
\text { innovative } \\
\text { approaches } \\
\text { to improve } \\
\text { education } \\
\text { (12) }\end{array}$ & $\begin{array}{l}\text { Engaging local } \\
\text { community in } \\
\text { a shared vision } \\
\text { for education } \\
\text { in the area (6) }\end{array}$ & $\begin{array}{l}\text { Reconciling } \\
\text { opposing } \\
\text { points of view } \\
\text { and } \\
\text { summarising } \\
\text { agreed points } \\
\text { (21) }\end{array}$ \\
\hline Leader 1 & $\begin{array}{l}\text { Meticulous } \\
\text { monitoring } \\
\text { of outcomes } \\
\text { for } \\
\text { pupils/learners } \\
\text { (20) }\end{array}$ & $\begin{array}{c}\text { Setting } \\
\text { ambitious } \\
\text { targets and } \\
\text { maintaining } \\
\text { clear focus } \\
\text { on achieving } \\
\text { financial as } \\
\text { well as educa- } \\
\text { tional/academic } \\
\text { goals (18) }\end{array}$ & $\begin{array}{c}\text { Strategic } \\
\text { vision based } \\
\text { on shared } \\
\text { values (4) }\end{array}$ & $\begin{array}{l}\text { Taking decisive } \\
\text { action to } \\
\text { address poor } \\
\text { performance of } \\
\text { staff teams e.g., } \\
\text { senior, middle } \\
\text { leaders, } \\
\text { curriculum } \\
\text { teams, pastoral } \\
\text { support (22) }\end{array}$ & $\begin{array}{l}\text { Values and } \\
\text { vision } \\
\text { developed and } \\
\text { owned by all } \\
\text { members of } \\
\text { staff and } \\
\text { governors (17) }\end{array}$ \\
\hline Leader 2 & $\begin{array}{c}\text { Taking } \\
\text { decisive } \\
\text { action to } \\
\text { address poor } \\
\text { performance } \\
\text { of staff teams } \\
\text { e.g., senior, } \\
\text { middle } \\
\text { leaders, } \\
\text { curriculum } \\
\text { teams, } \\
\text { pastoral } \\
\text { support (22) }\end{array}$ & $\begin{array}{c}\text { Balancing } \\
\text { financial } \\
\text { constraints } \\
\text { with } \\
\text { aspirational } \\
\text { educational } \\
\text { ambitions (3) }\end{array}$ & $\begin{array}{l}\text { Maximising } \\
\text { talent in the } \\
\text { team and } \\
\text { deploying } \\
\text { talent } \\
\text { effectively in } \\
\text { the } \\
\text { organisation } \\
\text { (9) }\end{array}$ & $\begin{array}{l}\text { Meticulous } \\
\text { monitoring of } \\
\text { outcomes for } \\
\text { pupils/learners } \\
\text { (20) }\end{array}$ & $\begin{array}{c}\text { Setting } \\
\text { ambitious } \\
\text { targets and } \\
\text { maintaining } \\
\text { clear focus on } \\
\text { achieving } \\
\text { financial as } \\
\text { well as educa- } \\
\text { tional/academic } \\
\text { goals (18) }\end{array}$ \\
\hline Leader 3 & $\begin{array}{c}\text { Balancing } \\
\text { financial } \\
\text { constraints } \\
\text { with } \\
\text { aspirational } \\
\text { educational } \\
\text { ambitions (3) }\end{array}$ & $\begin{array}{l}\text { Meticulous } \\
\text { monitoring } \\
\text { of outcomes } \\
\text { for } \\
\text { pupils/learners } \\
\text { (20) }\end{array}$ & $\begin{array}{c}\text { Taking } \\
\text { decisive } \\
\text { action to } \\
\text { address poor } \\
\text { performance } \\
\text { of staff teams } \\
\text { e.g., senior, } \\
\text { middle } \\
\text { leaders, } \\
\text { curriculum } \\
\text { teams, } \\
\text { pastoral } \\
\text { support (22) }\end{array}$ & $\begin{array}{c}\text { Setting } \\
\text { ambitious } \\
\text { targets and } \\
\text { maintaining } \\
\text { clear focus on } \\
\text { achieving } \\
\text { financial as } \\
\text { well as educa- } \\
\text { tional/academic } \\
\text { goals (18) }\end{array}$ & $\begin{array}{l}\text { Maximising } \\
\text { talent in the } \\
\text { team and } \\
\text { deploying } \\
\text { talent } \\
\text { effectively in } \\
\text { the } \\
\text { organisation } \\
\text { (9) }\end{array}$ \\
\hline Leader 4 & $\begin{array}{l}\text { Engaging } \\
\text { local } \\
\text { community } \\
\text { in a shared } \\
\text { vision for } \\
\text { education in } \\
\text { the area (6) }\end{array}$ & $\begin{array}{l}\text { Develop en- } \\
\text { trepreneurial } \\
\text { innovative } \\
\text { approaches } \\
\text { to improve } \\
\text { education } \\
\text { (12) }\end{array}$ & $\begin{array}{c}\text { Balancing } \\
\text { financial } \\
\text { constraints } \\
\text { with } \\
\text { aspirational } \\
\text { educational } \\
\text { ambitions (3) }\end{array}$ & $\begin{array}{l}\text { Taking decisive } \\
\text { action to } \\
\text { address poor } \\
\text { performance of } \\
\text { staff teams e.g., } \\
\text { senior, middle } \\
\text { leaders, } \\
\text { curriculum } \\
\text { teams, pastoral } \\
\text { support (22) }\end{array}$ & $\begin{array}{c}\text { Meticulous } \\
\text { monitoring of } \\
\text { outcomes for } \\
\text { pupils / learners } \\
\text { (20) }\end{array}$ \\
\hline
\end{tabular}


Table 3 shows that in the original study (highlighted in grey) the five most strongly disagreed statements, indicate the relative lower priority given by respondents to the wider context and policy environment in education, such as passion for providing world class education, developing entrepreneurial and innovative approaches and engaging the local community in a shared vison of education. However, it is very noticeable that the priority given by leaders in this follow-up research are statements linked to the meticulous monitoring of standards (20), balancing financial constraints (3), taking decisive action around performance (22) and the setting of ambitious targets (18).

Prior to the pandemic school budgets had been limited at best but given these times of turbulence, extra monies had to be spent to stabilise and mitigate against the issues leaders faced. Before the pandemic funding concerns for leaders had, for example, centred around supporting staffing levels. However, in these times of turbulence new items and many new spending foci had to be funded in addition to the normal historic spending regime encountered by schools. This included extra cleaning of school premises, purchasing additional cleaning materials and items of personal protective equipment (PPE). For all leaders the limited monies available through central government funding proved insufficient to cover such costs. Leader 1 pointed out:

We just limped through with the budget. If there were additional costs they just had to be met ... you had to let go of that and release the usual anxiety you have around that, there was just so much else you had to focus on.

All leaders saw such spending as being vital to their attempts to reopen schools safely and to keep their stakeholders safe. Such overspends were agreed by leaders and governors, as Leader 4 noted:

I said very early on to the finance committee of our governing body that there are cost centres that are just going to have to go over, there is nothing we can do we just have to have these spends (PPE, extra cleaning) we just have to sit tight and wait to see what comes out the other end.

Some leaders who were lucky enough to hold a continency fund saw this as being the best way to resolve any financial shortfall. Leader 2 said:

We have to keep an eye on the finances definitely but there are going to be, what is a contingency for but a rainy day and I would suggest it is a rainy day at the moment.

For leaders the focus on 'meticulous monitoring of outcomes for pupils/learners' (20) and 'setting ambitious targets and maintaining clear focus on achieving financial as well as educational/academic goals' (18) seemed now less important given the complexity of a turbulence. They all agreed that outcomes for pupils were still of paramount importance. However, given governmental changes in policy regarding testing and examinations, the agenda leaders were facing had morphed into concerns about continued learning, access to learning and caring for and supporting the wellbeing of their pupils. As Leader 1 suggested:

There has been a complicit understanding, with for example SATs off the table that we cannot work to the same agenda. Standards are always important, no right minded professional would say not, but perhaps the way the whole teaching body is held to account, that is a sort of thing we could suspend for a year.

The use of remote learning to maintain teaching and learning for their pupils became a major focus for school leaders. Hitherto the pandemic, face to face teaching and learning was the norm and the use of virtual platforms part of a limited offer of remote activities, e.g., promoting additional resources/learning, homework, communicating with school stakeholders. For most staff, both their skill levels in using virtual platforms and their usage of such technologies were limited. The pandemic meant that remote teaching and learning alongside the monitoring of pupil's engagement with this medium meant that leaders focus had to change. As Leader 2 commented: 
You have to be pragmatic, no way we can really monitor closely outcomes, what children are doing ... is unrealistic to think we are going to do it in the same way as we can do it in the classroom ... if a child is involved in a live teaching or seems to be on the screen, they might be but actually their engagement might be very limited, they might just have the screen on, how do we know they are actually engaging so it's going to be very difficult to measure how well they are getting on.

Leader 1 suggested:

We are assessing our children continuously through this virtual existence of ours but what we will put in place, we will catch up, but it is the children's emotional health and wellbeing that is really important.

It was the key word 'meticulous monitoring' that had resonances of where such an item could be placed in a leader's priorities. The remit of a turbulence meant the monitoring focus had now changed. As Leader 4 said:

Although we were engaging in remote learning what wasn't important about that was the monitoring the meticulous outcomes of that it was the fact that they were engaged... that things were ticking over. I was monitoring engagement, we were doing all the usual things, phone calls home and all of that but the monitoring was a completely different kind to what would be our bread-and-butter standards monitoring.

Leaders felt it was less about having to 'take decisive action to address poor performance' (22). The focus was on wellbeing and accepting that everyone was doing their upmost given a turbulence that was now inescapable. They felt their usual benchmarks had now gone. That it was just being realistic about the levels at which individuals could perform at given their own personal constraints. As Leader 4 suggested:

There was no question of monitoring that performance in any way. We knew and believed that they were doing the best that they could and that was good enough. That was good enough for me that people were turning in, despite their levels of anxiety, they were doing their job to the best of their ability ... so managing performance goes out the window in that scenario I am afraid.

\section{Discussion}

For many leaders and managers, a time of turbulence, presented in this case by COVID-19, has been a once in a generational challenge for their leadership. As with any crisis it has been a time of urgency as [1] suggest where swift and decisive actions are needed. This current turbulence has been a time where the norms of providing an outstanding education have been challenged and doubt about whether such a goal was possible. For leaders working in such turbulence what would seem vital, as [7] suggests, is for leaders and managers to seek, critically assess and then through their careful choices of ideas and practices [7] (p. 44) develop a culture of change.

When considering our findings, the conceptualisation of leadership suggested by [11] is helpful as it outlines the qualities and practices of outstanding primary school leadership. The framework can provide us with a lens to reflect upon the characteristics of outstanding leadership in a time of turbulence. By considering what the leaders are like as people, what do they do and how do they do it [11], we may gain an insight into what we as leaders need to do to be successful in any future times of turbulence.

From the findings of this study which are also reflected in the research of [1], it is clear how important strong leadership is in driving forward strategic change and innovation. As the study shows and as [2] suggests, school leaders need to be flexible and reactive in order to deal with such sudden and swift changes as a result of a crisis. This is in order to secure the best educational outcomes for their pupils. What leaders are like as people is more important than ever given ongoing turbulence as this study has shown. For it is a leader's personal traits and qualities, as seen by $[18,20]$ that are fundamentally important for successful leadership. With such a moral purpose, allied to a leader's 'personal leadership resources', their 'social appraisal skills' or 'emotional intelligence' [20] (p. 14) being also 
necessary for a leader's efficacy, both in ordinary, as well as times of turbulence. As the findings have shown it is a leader's ability, using these 'personal leadership resources' that will matter if their efforts to lead and work with colleagues to make a cohesive and effective team are to be successful.

In times of turbulence personal qualities and characteristics are important if schools are to continue to succeed and thrive given the constant challenges being presented to them. It is a leader's care for others, emotional support and encouragement that are necessary if leaders are to convince others that we are on a learning journey and all can succeed in the adverse circumstances encountered. For all to succeed as [2] suggest, the most effective school leaders must build upon the talents, knowledge and competences of professionals. For one leader in our study, it was felt that it would be counterproductive to be anything other than be supportive and open. For this leader 'compassionate leadership' summed up the best approach they could adopt given the turbulence they faced. Surely such an approach must also be a lesson for the future for all leaders. If they are to be in a position to attract and retain the best staff for their schools, leaders must, not only in times turbulence, show compassion to individuals but also care and give emotional support for the challenges they will face both professionally and personally.

In our previous study [12], leaders agreed that high expectations of all members of staff and pupils was the most important characteristic relating to outstanding leadership. However, in this follow-up research, what has shown as being most important in a time of turbulence are a leader's vision and values, underpinned by strong relationship with stakeholders. Just as importantly those who follow must also buy into and have confidence in what is being suggested by their leaders. In turn leaders need to have a clarity of focus and a sense of conviction in their own minds about what it is they wish to achieve and how they must go about this. As other researchers [21-24] have also shown, practices that link to what leaders do [11] to build success need to be established. These include developing a shared vision, establishment of effective teams, building trust and collaboration both within the school, with parents and the wider community. With turbulence, change is inevitable and what is important is involving everyone in a shared understanding and ownership of what is borne out of necessity.

Given such turbulence, as [1] indicate, leaders need to not only support staff and pupils but also align a school's future to ensure it may achieve its goal in achieving the best in teaching and learning. Part of any drive from leaders to produce an outstanding education in times of turbulence will involve personal investment in others. It will require a leader's expectation of staff to be tempered by the knowledge that staff are doing their upmost to weather such turbulence. In times of turbulence, it is less about leaders maximising talent and deploying staff effectively and more about accepting that the circumstances individuals are now in and their personal and professional constraints will inevitably impact upon everyone's ability to deliver the best education possible.

Fundamental to effective leadership in times of turbulence are good personal and interpersonal relationship with all stakeholders underpinned by trust [10]. Such resources need to be continually built by leaders in times of normality so that they may act as 'a reservoir of goodness' that can be drawn on at times of turbulence. These characteristics are echoed in the benchmark standards for headteachers in England [25] and have been expounded by authors writing about leadership for successful schools [26]. Trust enables the development of a sense of personal regard for others and in times of turbulence high regard for others is significant in providing a cohesive glue that sees individuals through testing and difficult times. For researchers, such as [27], it is the personal and emotional commitment of leaders that can have a direct impact upon the teams they manage and schools they lead. As with our findings, it is the promotion of an open culture, a concern for others and a feeling that everyone is important in this turbulence that leads to success. It is in such times, as [28] (p. 392) rightly suggests that leadership is 'not a title but an action, a behaviour, a practice, a doing and a way of being'. In our findings, the leader of one of the smallest schools commented that in times of turbulence it was important that they should 
be an inspirational leader that could lead by example. As they noted, this could be much easier in a small school, to be one of the community doing the same as everyone else. They acknowledged that running a bigger school could sometimes make this leadership role more difficult.

It would seem obvious that in times of turbulence for leadership to be effective, key and sometimes difficult decisions need to be made. In more ordinary times such decisions would normally be linked to items such as budgetary decisions leading for example to implications for staffing levels. However, in times of during turbulence this focus changed dramatically to that of crisis management and supporting individuals through their own issues, as illustrated by comments from Leader 1 and Leader 2 in our sample. The focus for leaders as a key concern shifted to issues such as mitigating risk to individuals. Given the uncertainty of the ongoing turbulence leaders may face difficult decisions in future. For example, how to square the overspend on items such as PPE if extra funding is not provided, how to maintain levels of staffing if priorities such as extra cleaning is to be provided for safety reasons. If governments truly wish schools to achieve a high standard of education in the future a long deep look will be necessary as to what a school's priorities should be post turbulence and how they can be funded.

It was suggested that again relationships were key and as with normal times a leader's interpersonal skills of reconciling opposing points of view through an open and honest dialogue vital to see them and their setting through such turbulence. As [28] suggests when delivering education, it is humanity rather than outcomes that should be considered.

In findings from our original study a high priority was given by leaders to the wider context and policy environment of standards in education whilst this seemed a distant thought for leaders during the turbulence brought about by the COVID-19 pandemic. That is not to say leaders were not concerned with children's achievements and educational standards but the removal of national external tests and examinations meant the benchmarking of schools was put on hold. Leaders had been freed from such concerns, with their focus now being on how education could best be continued and promoted. Their concerns linked to continued learning, access to learning and caring for and supporting the wellbeing of their pupils.

The leaders we interviewed noted that it seemed inappropriate to take decisive action to address poor performance. This was linked to the pressure on individuals both due to their personal and professional circumstances. Given the removal of the standards benchmarks to measure staff's effectiveness with regards to promoting achievement, it was as one leader commented "just being realistic about the levels at which individuals could perform at given their own personal constraints". The focus of decisions had changed from that of personal accountability, decisions around financing and standards to more management focused items, for example how items around hygiene and personal protection could be delivered and enforced. In a time of turbulence, where circumstances changed and only key workers could attend schools and distant virtual learning became the norm, notions of the 'meticulous monitoring of outcomes for pupils/learners' and 'setting ambitious targets and maintaining clear focus on achieving financial as well as educational/academic goals' seemed less important given the complexity of the times.

The findings show how necessary it has become for individuals to deliver online learning to their pupils both for academic and wellbeing reasons. This pandemic has taught us that leaders, teachers, pupils and families can adapt quickly if needed. Though for some the biggest challenge has been overcoming the digital literacy levels needed to engage successfully with learning platforms. It has also drawn into sharp focus for leaders, especially during the initial periods of the pandemic, the inequalities and practical difficulties that children and families have faced when accessing a virtual world of learning. These include a poor internet connection, lack of freely available computing hardware and the competition for computing time. This has been especially acute given the competing demands placed on accessing the internet for children's learning versus its use for parent's work. The ongoing turbulence has, despite all these challenges, given leaders an insight 
into the best that an online world can offer, for example to reach individuals when access is difficult and to save time in travelling to meet with one another which can be better used for other purposes. With the return of children into the classroom however it has set leaders the challenge of closing the gap between the range of learning levels achieved during these times. It will also mean for leaders that many difficult financial, practical and pedagogical decisions will be needed in the future to deal with the consequences of these turbulent times. However, there can be no doubt, a virtual/face to face hybridized future awaits us. This may surely be one of the lasting legacies of our turbulent times, something that will last into our distant futures.

Pragmatism was the mantra for some leaders given the difficulties of assessing pupils progress with the limited insights into their learning environment and engagement on the task in hand. For leaders the concern for pupil achievement went hand in hand with a concern for the emotional and physical health and wellbeing of others. Something that is important not only in times of a pandemic but also for the future if leaders wish individuals to thrive in whatever they do. A leader's role and priorities had now, as [29] rightly pointed out been transformed to alleviating staff workload, supporting teaching due to teachers who needed to self-isolate due to COVID-19 or implementing daily safety procedures. Such considerations of roles extended far beyond that of daily procedures and roles as a leader but also strategic decision making about how the curriculum was to be delivered in a COVID safe way.

The literature relating to educational leadership and management in times of crisis is limited [1,30]. However, as [13] rightly state, there is little empirical research which examines change leadership in times of such a national crisis or with regards to such ongoing levels of turbulence. Therefore, this work in some way wishes leaders to reflect upon the exemplification of the characteristics of effective leadership in times of turbulence given above. As this study has shown, it is in times of crisis, as [2] notes, that the practice of school leadership undergoes considerable change, or even irreversible change. When considering change some activities and priorities will remain and other will diminish as this turbulence passes. It is also important to note that for leader's context is important in any time of turbulence. As with any research relating to the field of leadership and management a consideration of the context in which it happens is vital, no more so given the ongoing nature of the pandemic. It allows for an understanding of the factors that will make for the successful provision of an effective education. Though as [18] (p. 8) indicate, context alone should not be considered as a singular marker of success. Context seems even more important when considering what makes for effective practice and successful leadership at these challenging of times, a time which needs to put individuals at the heart of the success.

Author Contributions: Conceptualization, C.H. and J.K.D.; methodology, J.K.D. and C.H; formal analysis, C.H.; investigation, C.H.; writing - original draft preparation, C.H and J.K.D.; writingreview and editing, J.K.D. and C.H.; All authors have read and agreed to the published version of the manuscript.

Funding: This research received no external funding.

Institutional Review Board Statement: Ethical approval was obtained from the University of Worcester Ethics Committee. University of Worcester and British Educational Research Association (BERA) guidelines for ethical research were followed through all stages of the research process.

Informed Consent Statement: Informed consent was obtained from all participants involved in the study.

Data Availability Statement: The anonymised data is available from the authors.

Conflicts of Interest: The authors declare no conflict of interest. 


\section{References}

1. Smith, L.; Riley, D. School leadership in times of crisis. Sch. Leadersh. Manag. 2012, 32, 57-71. [CrossRef]

2. Harris, A. COVID-19-school leadership in crisis? J. Prof. Cap. Community 2020, 5, 321-326. [CrossRef]

3. Harris, A.; Jones, M. COVID 19-Leadership in crisis. Sch. Leadersh. Manag. 2020, 40, 243-247. [CrossRef]

4. McNulty, E.J.; Marcus, L.J.; Joseph, M.; Henderson, J.M. Crisis leaders? Prepare to lead when it matters most. Lead. Lead. 2019, 2019, 33-38. [CrossRef]

5. McLeod, S.; Dulsky, S. Resilience, reorientation, and reinvention: School leadership during the early months of the COVID-19 pandemic. Front. Educ. 2021, 6, 637075. [CrossRef]

6. Ofsted COVID-19 Series: Briefing on Schools. 2020. Available online: https://assets.publishing.service.gov.uk/government/ uploads/system/uploads/attachment_data/file/933490/COVID-19_series_briefing_on_schools_October_2020.pdf (accessed on 23 July 2021).

7. Fullan, M. Change Forces: The Sequel; Falmer Press: London, UK, 2001.

8. Day, C.; Sammons, P. Successful School Leadership; Education Development Trust: Reading, UK, 2014.

9. Ferguson, P.; McKenzie, M.; Mercieca, D.; Mercieca, D.P.; Sutherland, L. Primary head teachers' construction and re-negotiation of care in COVID-19 lockdown in Scotland. Front. Educ. 2021, 617869. [CrossRef]

10. Sutherland, I.E. Learning and growing: Trust, leadership, and response to crisis. J. Educ. Adm. 2017, 55, 2-17. [CrossRef]

11. Matthews, P.; Rea, S.; Hill, R.; Gu, Q. Freedom to Lead: A Study of Outstanding Primary School Leadership in England; National College for Teaching and Leadership: London, UK, 2014.

12. Dhillon, J.K.; Howard, C.; Holt, J. Outstanding leadership in primary education: Perceptions of school leaders in English primary schools. Manag. Educ. 2019, 34, 61-68. [CrossRef]

13. Beauchamp, G.; Hulme, M.; Clarke, L.; Hamilton, L.; Harvey, J.A. 'People miss people': A study of school leadership and management in the four nations of the United Kingdom in the early stage of the COVID-19 pandemic. Educ. Manag. Adm. Leadersh. 2021, 49, 375-392. [CrossRef]

14. Ramlo, S. Mixed method lessons learned from 80 years of Q-methodology. J. Mix. Methods Res. 2016, 10, 28-45. [CrossRef]

15. British Educational Research Association (BERA) Ethical Guidelines for Educational Research, 4th ed.; British Educational Research Association: London, UK, 2018.

16. Stephenson, W. General Theory of Communication. Operant Subj. 2014, 37, 38-56. [CrossRef]

17. Willig, C.; Stainton-Rogers, W. The SAGE Handbook of Qualitative Research in Psychology; SAGE Publications Ltd.: London, UK, 2013.

18. Leithwood, K.; Day, C.; Sammons, P.; Harris, A.; Hopkins, D. Seven Strong Claims about Successful School Leadership; NCSLCS: Nottingham, UK, 2006.

19. Day, C.; Sammons, P.; Hopkins, D.; Harris, A.; Leithwood, K.; Qing, G.; Brown, E. 10 Strong Claims about Successful School Leadership; NCSLCS: Nottingham, UK, 2010.

20. Leithwood, K.; Harris, A.; Hopkins, D. Seven strong claims about successful school leadership revisited. Sch. Leadersh. Manag. 2019, 40, 5-22. [CrossRef]

21. Barber, M.; Whelan, F.; Clark, M. Capturing the Leadership Premium; NCSLCS: Nottingham, UK, 2010.

22. Bush, T. Leadership and Management Development in Education; Sage: London, UK, 2008.

23. NCSL (National College for School Leadership). What We Know about School Leadership; NCSL: Nottingham, UK, 2007.

24. Dhillon, J.K. Senior managers' perspectives of leading and managing effective, sustainable and successful partnerships. Educ. Manag. Adm. Leadersh. 2013, 41, 736-750. [CrossRef]

25. Headteachers' Standards 2020. Available online: https://www.gov.uk/government/publications/national-standards-ofexcellence-for-headteachers/headteachers-standards-2020 (accessed on 25 May 2021).

26. Tschannen-Moran, M. Trust Matters: Leadership for Successful Schools; Jossey-Bass: San Francisco, CA, USA, 2004.

27. Hargreaves, A.; Fullan, M. Professional Capital: Transforming Teaching in Every School; Teachers College Press: New York, NY, USA, 2012.

28. Netolicky, D.M. School leadership during a pandemic. J. Prof. Cap. Community 2020, 5, 391-395.

29. Ofsted Guidance School Inspection Handbook. Available online: https://www.gov.uk/government/publications/schoolinspection-handbook-eif/school-inspection-handbook (accessed on 28 May 2021).

30. Gainey, B. Crisis management's new role in educational settings. Clear. House 2009, 82, 267-274. [CrossRef] 